R. História, São Paulo, n. 122, p. 17-46, jan/jun. 1990

\title{
CAMINHOS E FRONTEIRAS: O MOVIMENTO NA OBRA DE SÉRGIO BUARQUE DE HOLANDA,
}

\author{
Ilana Blaj ${ }^{1}$ \\ Marina Maluf ${ }^{2}$
}

RESUMO: O artigo pretende realçar a idéia de movimento no espaço e no tempo presente em Sérgio Buarque de Holanda, tomando como referência básica a obra Caminhos e Fronteiras.

Através de uma pesquisa minuciosa que tem como base o fazer e refazer cotidiano, $o$ autor vai construindo dialeticamente a interação meio/sociedade/cultura, isto é, a relaçáo tensional entre patamares diferentes de civilização consubstanciados no colono europeu e no início do planalto paulista. Sua obra é elaborada em torno da idéia de movimento, das tensôes do devir, onde realidade, método, estilo são uma só e mesma coisa. Assim, Caminhos e Fronteiras não é apenas o título de um de seus livros mas é toda sua obra, onde a realidade está sintetizada no movimento dos caminhos e nas tensóes das fronteiras.

Ler Sérgio Buarque de Holanda é mergulhar no cotidiano, no movimento e nos agentes do cotidiano. Nas práticas, nas experiências, nos costumes, nas formas repetidas e inovadoras de vida, nos fracassos e nas conquistas que fazem a história.

O cotidiano é a base sobre a qual Sérgio Buarque de Holanda reconstrói o passado histórico; vai mais além ao focar seu olhar de observador atento tomando-o como fonte, pois entende que a transformação, a mudança, o devir histórico enraizam-se nas múltiplas urdiduras do "fazer" cotidiano: É pois este o lugar onde se trama o "fazer" e o "refazer" da vida humana, plena de possibilidades, de promessas, projetos, "agouros". Assim, a evidéncia e a

1 Prof no Departamento de História da FFLCH/USP.

2 Prof no Departamento de História da PUC:/São Paulo. 
BLAJ, Ilana e MALUF, Marina. Caminhos e fronteiras: o movimento na obra de Sérgio Buarque de Holanda.

importância do cotidiano resgatada através da pesquisa acaba por se impor, derramando-se sobre os modelos teóricos de caráter "apriorístico", forçando o autor a esgarçá-los. Os ritmos, as temporalidades, os percursos não conhecem o desenvolvimento prévio, ao contrário: a surpresa, a imprevisibilidade, os avanços e recuos, os silêncios, os anônimos, o rotineiro, o singular, o inconsciente, o mágico é que se entretecem construindo o significado, o sentido mesmo de cada época histórica. O ofício do historiador é um aproximar-se deste fazer, seja em que nível for, já que a urdidura do cotidiano é a única capaz de guardar e explicar os múltiplos acontecimentos, tanto os que náo passaram de tentativas, quanto os que acabaram por assumir uma feição vitoriosa.

Tomar o cotidiano como base e como fonte exige a elaboração de um procedimento onde este não aparece nem como referência, nem como ilustração: é o próprio processo histórico apreendido e configurado de uma maneira viva e crítica. Refazer o cotidiano é na obra deste autor ao mesmo tempo procedimento, estilo, interpretação. Constrói e reconstrói numa mesma linguagem, qual seja, aquela que dê conta de nẫo fragmentar a experiência humana em compartimentos racionalizados e portanto reduzidos e cristalizados por um determinado tipo de experiência analítica.

Como o autor vai dar significado a este cotidiano e a este modo cotidiano de trabalhar? Cada época tem para Sérgio Buarque de Holanda seu próprio centro de gravidade, sua unidade de sentido, que o historiador deverá apreender através da "compreensão". A "compreensão" neste sentido, e o próprio conhecimento histórico: é o meio e a forma de representação do passado. A "compreensão" coloca a questão da natureza do conhecimento histórico e das formas de representação do passado. O passado ganha sentido através da "compreensão". Deslindar as práticas cotidianas de existência reconhecendo nelas a constante interação tensional meio-cultura-sociedade é construir as totalidades significativas de cada época.

A interação meio-cultura-sociedade é sempre tensional. Não é polarizada porque não é o choque entre o novo e o velho; não é mera assimilação funcional, porque o novo não sucede o velho num encadeamento lógico necessário. A tensão advêm da simultaneidade com que tradicional, novo e mais novo, como três elementos antagônicos, portanto inseparáveis, ganham sentido e garantem o movimento dialético. No dizer de Maria Odila Leite da Silva Dias "as tensōes do devir, o movimento e confronto de forças contraditórias, que se opunham numa certa época e chegavam, às vêzes, a exaurir-se, após impasse crítico, do qual 
emergiam formas e forças novas, que transformavam os homens e seus "modus vivendi" ${ }^{3}$.

O movimento não cessa nunca. A interação meio-sociedade-cultura prođuz uma sedimentação provisória que é a síntese, que por guardar a negação de si mesma, de forma latente, descontrói-se em algo mais novo. $\mathrm{O}$ movimento continua.

Sérgio Buarque de Holanda elabora sua obra em torno da idéia de movimento, das tensóes do devir. Nele, realidade, método, estilo não aparecem como etapas do processo de conhecimento; são uma só e mesma coisa, onde os ritmos da realidade, os procedimentos compreensivos e a configuração do passado formam uma totalidade cuja sonoridade e cadência são dadas pelo próprio fazer e desfazer da prática cotidiana.

Assim, o eixo temático que ordena este artigo, centrado no livro Caminhos e Fronteiras, mas que reúne também outras obras de Sérgio Buarque de Holanda ${ }^{4}$, é a idéia de caminho e a idéia de fronteira, em vários níveis. Desde o movimento do próprio trabalho do autor onde tempo e objeto se constituem mutuamente no seu próprio movimento, até o sentido mais metafórico onde caminho é devir, que se opõe à linearidade e causalidade necessárias. É a idéia de que o vir-a-ser da história não é previsível mas é movimento surpresa: idéia do "aluvional" e do "movediço", pois a fronteira implica em tensão, antagonismo: idéia da "sangria" onde as forças tradicionais, novas e mais novas simultâneamente se entrecruzam, produzindo mecanismos de acomodação que transfiguram o velho e remodelam o novo.

Caminhos e Fronteiras não é pois o título de uma de suas obras mas é toda sua obra, onde a realidade está sintetizada no movimento dos caminhos e nas

3 DIAS, Maria Odila Leite da Silva org. Sergio Buarque de Holanda, Col. Grandes Cientistas Sociais, Sấo Paulo: Ática, 1985, p. 17.

4 As obras analisadas neste artigo foran: Caminhos e Fronteiras. Rio de Janeiro: José Olympio, 1957; Monçöes. $2^{n}$ ed.. São Paulo: Alfa-Ômega, 1976; Movimentos de População em Säo Paulo no século XVII, In: Revista do Instituto de Estudos Brasileiros. São Paulo: USP, n.1, 1966; "Metais e Pedras Preciosas" In: História Geral da Civilização Brasileira. $2^{\mathrm{a}}$ ed.. São Paulo: Difusão Européia do Livro, 1968, tomo I, $2^{\circ}$ vol.; "A Herança Colonial - sua desagregação". In: História Geral da Civilização Brasileira. $5^{n}$ ed.. São Paulo: Difel, 1982, tomo II, $2^{\circ}$ vol.; "SÃO PAULO". In: História Geral da Civilizaçäo Brasileira. $2^{\mathrm{a}}$ ed.. São Paulo: Difel, 1967, tomo II, $2^{\circ}$ vol. 
BLAJ, Ilana e MALUF, Marina. Caminhos e fronteiras: o movimento na obra de Sérgio Buarque de Holanda.

tensões das fronteiras. A fronteira leva ao caminho e o caminho leva à fronteira: é o próprio movimento dialético.

A afirmação contida na colonização idealizada (tese) traz consigo o mito edênico, a remissão, a busca da honra pela cobiça, o alargamento do espaço metropolitano; a realidade do novo meio faz sua primeira negação, quando então o adventício é obrigado a rebaixar seu patamar de civilidade, para poder continuar sonhando (antítese). É a experiência das tensões da fronteira, onde nas palavras do autor:

"aqueles aspectos, precisamente, em que tal civilização, colocada perante contingências do meio, pode aceitar, assimilar e produzir novas formas de vida, revelando-se até certo ponto criadora e não somente conservadora de um legado tradicional nascido em clima estranho" ${ }^{5}$.

Faz-se a segunda negação: a transformação e produção de novas formas de vida e o mais novo que se traduz no movimento do caminho. A ação transformadora do meio obriga o adventício não só a guardar seu legado metropolitano como um patrimônio cultural necessário, como a desenvolver uma nova atitude, uma "vocação para o espaço" (síntese provisória). Assim, a "vocação para o espaço" tem uma determinação histórica, não é um dado natural, atributo do colono do planalto de Piratininga.

Podemos dizer que a interação meio-sociedade-cultura (fronteira) traz dentro de si a "vocação para o espaço" (caminho). Este é o movimento constante, desde os primórdios da expansão paulista até a fixação provisória que transformou "os primeiros sertanistas, homens intrépidos em retalhistas e homens de negócios"

Para Sérgio Buarque de Holanda, a história é o estudo do movimento, do vir-a-ser transformador, das tensões entre diferentes temporalidades e entre continuidade e ruptura. $\mathrm{O}$ lugar onde vai buscar a multiplicidade da vida é o

5 HOLANDA, Sérgio Buarque de. Monçöes, p. VIII.

6 DIAS, Maria Odila Leite da Silva. "De Monções a Caminhos e Fronteiras". In: Revista do Brasil. Rio de Janeiro: Prefeitura da Cidade do Rio de Janeiro/Rioarte-Fundaçăo. , ano 3,1987 , p. 63. 
cotidiano que, assim, se torna o campo histórico por excelência em sua obra. É no "perscrutar de processos espontâneos", singulares, que reside toda a força de seu trabalho. Parte de traços rotineiros, miúdos, hábitos consagrados, costumes adotados e, através de um estilo que procura a sonoridade das fontes, o espírito da época, estabelece relações, ampliando-as até atingir, compreensivamente, as totalidades significativas.

"Veredas de pé posto", título do primeiro capítulo de Caminhos $e$ Fronteiras, já traz em si a base sobre a qual o autor edificará toda a sua obra: o movimento que se expressa na simultaneidade dos caminhos e das fronteiras, isto é, nas tensões, na sedimentação provisória. Assim, não é à toa que Sérgio Buarque de Holanda elege "vereda" como ponto de partida mas não como ponto fixo de chegada. É o lidar com as palavras que ao mesmo tempo é tratamento metodológico e que vai se completar no estilo interpretativo. Veredas é a permanente multiplicação do movimento: é sinuosidade, é a surpresa barroca, é o ir e vir constante, é o próprio devir. Os pés postos nas veredas indicam um momento do movimento, a antítese, aquele momento onde se dá a assimilação que significa não a incorporação passiva de um legado pré-existente, mas tensão e que pode ser expressa na idéia de fronteira. Antítese porque, de um lado ou, num caminho, o do branco, há a negação pela insuficiência do seu legado metropolitano; de outro, embora o branco europeu incorpore enquanto necessidade traços da cultura indígena, no limite, ocorre a negação da civilização indígena, na medida em que o branco tem que negá-la para poder conservar 0 seu sonho: sua colonização idealizada.

Este sonho colonial choca-se com a realidade tropical aqui encontrada. Não há sinais de ouro, de riquezas aparentes no planalto de Piratininga, mas apenas veredas e atalhos, expressões geográficas e andejas do indígena. Como diz o autor em Monçōes: 7

"A mobilidade dos paulistas estava condicionada, em grande parte, a certa insuficiència para nutrir os mesmos ideais de vida estavel, que nas terras da marinha puderam realizar-se, ao primeiro contato entre o europeu e o Novo Mundo... Em toda parte é idêntico o objetivo dos colonos portuguêses. Diverge unicamente, 
BLAJ, Ilana e MALUF, Marina. Caminhos e fronteiras: o movimento na obra de Sérgio Buarque de Holanda.

ditado por circunstâncias locais, o compasso que, num e noutro caso, dirige a marcha para esse objetivo".

O indígena, colado e descolado do meio, neste processo de interação constante, desenvolvera um arguto sentido de observação, de identificação de perigos, de acidentes geográficos, de abertura e do refazer constante de trilhas, de formas de caminhar, etc... . Nas palavras do autor:

"Em lugar de ser simples escravo de suas aptidões naturais, dos cinco sentidos, que tinha excepcionalmente apurados, o índio tornava-se, assim, o senhor de um admirável instrumento para triunfar sobre as condições mais penosas e hostís. Podia disciplinar metodicamente muitas daquelas aptidões; criar e recriar mil e um recursos adequados a cada situação nova, sujeitar-se, onde fossem necessários, a comportamentos que the garantissem meios de subsistência. Dentro dos limites que lhe permitia sua técnica, dentro do sistema de avanços e recuos, de liberdades e submissões em que se agitava, também podia desenvolver ao máximo um poder inventivo orientado para o bem do grupo, como se deve esperar de homens para quem o viver era antes e acima de tudo um conviver ${ }^{\prime \prime} 8$.

$\mathrm{O}$ adventício necessita de todo este instrumental indígena e do próprio indígena como um momento necessário para sua sobrevivência. É o processo tensional de assimilação que significa desejar, necessitar algo de outrém, implica portanto numa consciência da alteridade, numa consciência do outro que é o portador de uma sabedoria que deve ser conquistada/assimilada.

Assim, conforme Sérgio Buarque de Holanda:

O retrocesso a condiçóes mais primitivas, a cada novo contato com a selva e com o habitante da selva, é uma etapa necessária nesse feliz processo de aclimação ${ }^{\prime \prime}{ }^{9}$.

8 HOLANDA, Sérgio Buarque de. Caminhos e Fronteiras, p. 22.

9 HOLANDA, Sérgio Buarque de. Monçöes, p. 18. 
ou como afirma em Monções:

"Retrocede... a padróes rudes e primitivos: espécie de tributo exigido para um melhor conhecimento e para a posse final da terra. Só muito aos poucos, embora com extraordinária consistência, consegue o europeu implantar, num país estranho, algumas formas de vida, que ja lhe eram familiares no Velho Mundo. C'om a consistência do couro, não a do ferro ou do bronze, dobrando-se, ajustando-se, amoldando-se a todas as asperezas do meio".10

Nesse movimento dialético de criação e negação, o legado metropolitano, guardado como patrimônio necessário, tem o seu lugar. Em A Herança Colonial - sua desagregação, releva-se o papel deste legado. Agora, trata-se já do legado colonial, mas que ainda guarda íntimas relações com o metropolitano:

"A circunstância de se terem mantido aqui $e$ nacionalizado, depois da Independência, as velhas ordens honorificas, denuncia bem como, ainda neste capítulo, os fundadores do Império do Brasil andaram longe, com poucas exceções, de querer fazer tábua rasa de todas as instituições herdadas da metrópole" ${ }^{11}$.

Em C'aminhos e Fronteiras, se o caminhar nas veredas exige o pé descalço, uma determinada forma de andar, nos povoados é o sapato, símbolo da ascenclência, que ao ser calçado, atualiza, repõe a dignidade do conquistador.

Dessa forma, as tensões constantes, razão e resultado do movimento dialético, colocam em interação permanente meio/cultura/sociedade; indio/português/mameluco. mameluco e a nova cultura que aqui se desenvolve são ao mesmo tempo o terceiro ele mento dessas tríades e o mais novo que emerge, que se traduz nas sedimentações provisórias. Neste momento da colonização, a sedimentação transforma o índio não só em escravo, em administrado, mas também em guia-aliado, em desbravador de "veredas de pé posto". O saci e o curupira, pensados com dois pés, com os calcanhares voltados para a frente,

10 HOLANDA, Sérgio Buarque de. Monçöes, p. 20.

11 HOLANDA, Sérgio Buarque de. A Herança Colonial - sua desagregação, p. 32. 
BLAJ, Ilana e MALUF, Marina. Caminhos e fronteiras: o movimento na obra de Sérgio Buarque de Holanda.

habitam as lendas que o imaginário criou. Eles são talvez, a melhor representação de "veredas de pé posto", pois, camuflam o sentido da jornada, assustando o viajante nas veredas com os seus pés astuciosamente postos.

Concluindo: o projeto colonizador, com todo seu elenco de objetivos, na realidade americana do planalto, enfrenta um ritmo e um compasso para sua implantação, que acaba por desenvolver à margem e dentro da ação colonizadora uma sociedade concreta, porque criadora de novas formas de vida:

"Existe, é claro, a norma externa, ao menos como um modelo formal, pois qualquer sociedade de homens se há de pretender civil e bem composta. Mas como impedir que venham constantemente a tona os contrastes entre a idealidade e uma realidade tangivel $e$ bruta? $O$ que de tudo ressalta é a estrutura movediça que se desmancha, em partes, e se recompóe continuamente, ao sabor de contigências imprevisíveis" ${ }^{12}$.

É nesta margem de liberdade e necessidade que o colono vai desenvolvendo tais formas de vida. Assim, analisar essa criação é retraçar a experiência cotidiana, experiência essa que dialeticamente nega e cria.

A realidade forja seus próprios caminhos ressaltando "a distância que, no Brasil, separava as condições reais da situação legal do país" ${ }^{13}$; através das formas espontâneas da vida cotidiana o autor reconstrói criticamente a história. Não é uma mera constatação da existência do normativo e espontâneo, mas a certeza de que o espontâneo é o campo histórico por excelência e, portanto, através dele se torna possível o retraçar da realidade na sua forma compósita.

"Esse descrédito dos formalismos, a instabilidade nas maneiras de comportamento e a implantação fácil de modas novas e efêmeras, que tanto amarguram C'ritilo, são próprios de uma sociedade de meio aluvial como aquela, feita em sua maioria de hordas de imigrantes, que não conheceram, em sua terra de origem,

12 HOLANDA, Sérgio Buarque de. Metais e Pedras Preciosas, p. 297.

13 HOLANDA, Sérgio Buarque de. A Herança Colonial - sua desagregaçăo, p. 38. 
a oportunidade de assimilar os altos padrões de civilidade e luzimento" ${ }^{14}$.

Assim, para explicitar este contínuo movimento não recorre a uma causalidade mas às multiplicidades do fazer cotidiano, onde as tensões entre "a tradição e a mudança" se constituem como pano de fundo.

Este processo de assimilação tensional onde o legado pré-existente, a tradição, interage com novos elementos é um dos núcleos básicos do artigo $\mathrm{A}$ Herança Colonial - sua desagregação. Aqui, o legado colonial enquanto tradição, mas também enquanto sedimentação provisória, desempenha papel fundamental na definição/redefinição do liberalismo nascente, portanto na própria mudança.

"Os princípios que surgirão à tona com a implantação do liberalismo, se não mudam fundamentalmente as tendências herdadas do passado colonial, servem, contudo, para lhes dar direção diferente $^{\prime \prime 15}$.

Ou,

"Parece natural que, ao lado dessas tendências, provindas, em suma, de nosso passado colonial e, quando muito enriquecidas no novo regime, outras, muito mais distintamente ligadas ao reformismo liberal, tivessem meios de vicejar" ${ }^{16}$.

O trajeto que o autor irá percorrer em Caminhos e Fronteiras é o de tomar o mais particular, o evidente, o indispensável à sobrevivência como a àgua, a alimentação, a cura para, a partir daí construir compreensivamente 0 fato

14 HOLANDA, Sérgio Buarque de. Metais e Pedras Preciosas, p.299. Ou ainda em $A$ Herança Colonial - sua desagregação: "Por mais que fizessem os legisladores novos no sentido de dar expressáo diferente à vida nacional, é indiscutivel que os hábitos longamente estabelecidos se mostravam mais poderosos que as intenções inovadoras", Op. cit., p.38.

15 HOLANDA, Sérgio Buarque de. Ibidem, p. 29.

16 HOLANDA, Sérgio Buarque de. Ibidem, p. 36. 
BLAJ, Ilana e MALUF, Marina. Caminhos e fronteiras: o movimento na obra de Sérgio Buarque de Holanda.

histórico. Assim, o conhecimento da natureza pelos índios é apropriado tornando-se parte integrante da história. Sérgio Buarque de Holanda parte da necessidade de sobrevivência mais elementar do homem branco e chega, através de múltiplos caminhos e fronteiras, a patamares mais civilizados de sobrevivência do mameluco. É a rota que vai do bandeirante sem limites espaciais, ao tropeiro e ao monçoneiro já mais disciplinado, rota esta igualmente percorrida pelo historiador em todas as suas dificuldades, em todos os seus obstáculos, em suas mazelas, nas alegrias de novas descobertas e conquistas, no suar das febres e na cura pelas mezinhas, enfim, no viver dos anônimos protagonistas da história.

A necessidade de sobrevivência impõe, exige do adventício e cria este percurso que vai desde as formas mais primitivas de existência até as mais elaboradas e disciplinadas. O colono se vê obrigado a desenvolver uma "vocação para o espaço" que é ao mesmo tempo necessidade e atitude.

Em Movimentos da População em São Paulo no séc. XVII, a "vocação para o espaço" prende-se intimamente à cultura material, isto é, à necessidade de busca do "equilíbrio vital": assim,

"seria baldado querer explicar a mobilidade que distingue singularmente os homens do planalto, apelando apenas para seu coração aventureiro. À raiz dessa atividade expansionista, o que primeiro se há de frisar, cumpre redizê-lo, é a má distribuição dos solos e é, sobretudo, o mau uso deles, com o que logo se fazem imprestáveis. A atração exercida por areas espaçosas e vestidas de mato grosso, o acesso mais fácil à mão de obra indígena, que nessas áreas se pode empregar, além do mais, fora do alcance direto das justiças civis e das censuras eclesiásticas, a imunidade relativa a opressóes e punições que naturalmente confere a assistência em paragem êrma, tudo isso vai somar-se, como estimulante enérgico, àqueles fatores. Partir, para tal gente, é fugir à inanição ameaçadora e em muitos casos é fugir também a vinditas, rancores e extorsões" ${ }^{17}$.

17 HOLANDA, Sérgio Buarque de. Movimentos da População em Säo Paulo no séc. XVII, p. 92. 
Expansão e permanência se definem pois mutuamente: a expansão é ao mesmo "as muitas sangrias" dos núcleos "saturados" e o que assegura a permanência, a

"sobrevivência do tipo de sociedade ali formada... mais refrigério talvez do que esperança".

A expansão

"de um lado era suscitada pela propria estrutura social e econômica em que tradicionalmente assentava a vida das mesmas capitanias, de outro devia servir para conservar intacta aquela estrutura, ameaçada de deteriorar-se sempre que faltassem escoadouros por onde se verteriam os excedentes da população das vilas " $"$.

O verso e o reverso dos deslocamentos populacionais pode ser percebido com toda clareza na questão dos recrutamentos, conforme expõe o autor em São Paulo:

"nos lugares do interior, os que puderam furtar-se a primeira tentativa de alistamento forçado não duvidaram muitas vêzes em desamparar suas roças, metendo-se nos matos ou indo acolher-se nas capitanias vizinhas".

Já no século XIX,

"as fugas tomavam um aspecto de exôdo alarmante a ponto de se pretender que em algumas vilas, mormente as que se situavam junto às ruas da Capitania, era total a deserção nos povos" ${ }^{18}$. 
BLAJ, Ilana e MALUF, Marina. Caminhos e fronteiras: o movimento na obra de Sérgio Buarque de Holanda.

Mas por outro lado,

"a conscrição militar terá servido indiretamente para escoimar a Província de elementos que poderiam perturbar até às raizes a ordem politico-social no momento em que começasse a cambalear o antigo regime ${ }^{\prime 19}$.

No Capítulo II de Caminhos e Fronteiras Sérgio Buarque de Holanda parte daquilo que é mais vital para o homem: a água. Este elemento indispensável ganha uma qualidade neste capítulo: são as samaritanas do sertão, caridosas, beneficentes, boas, essenciais tanto para a expansão como para a fixação.

É novamente através da apropriação dos conhecimentos indígenas quanto à localização de nascentes e fontes, de árvores e plantas que contém água, que o paulista pôde continuar nos caminhos e chegar nas fronteiras com o Cuiabá. Segundo o autor:

"No traçado das estradas, como nos estabelecimentos de arraiais e povoaçóes, o problema da água desempenhou quase sempre papel de importancia primordial ${ }^{\prime 20}$.

"Pela configuração, pela coloração do terreno, por algum sinal só perceptivel a olhos experimentados, sabem dizer com certeza a senda que há de levar a alguma remota aguada" ${ }^{21}$.

Se a água indica o caminho, a boa qualidade da água e dos ares garante a fixação. Tanto os caminhos quanto as fronteiras tem nela seu elemento primordial; nos primeiros é a cultura do provisório onde poços e cisternas são abandonados após terem satisfeito as necessidades momentâneas do viajante; nos segundos são cacimbas, já mais permanentes, a partir do século XIX, nos povoados e aldeias.

No capítulo terceiro, novamente o autor dá demonstrações de como trabalha com pistas, tal qual uma investigação de detetive. É a partir de um

19 HOLANDA, Sérgio Buarque de. Ibidem, p. 439/440.

20 HOLANDA, Sérgio Buarque de. Caminhos e Fronteiras, p. 44.

21 HOLANDA, Sérgio Buarque de. Ibidem, p. 38. 
indício: $o$ arrancar de sobrancelhas e pestanas por índios de algumas tribos que o autor chega a analisar a importância para os aborígenes e paulistas da cera e do mel, título deste capítulo. Os fatos miúdos do cotidiano, o processo de localização das colméias e de colheita do mel são apreendidos através da interação meio/sociedade/cultura. Em alguns casos, estes métodos não são predatórios, preservando-se as colméias, principalmente em áreas não habitadas ainda pelo colono, mas por indígenas que em suas representações mitológicas valorizavam as abelhas, como alimento dos seus antepassados. Em outras, este labor já é predatório, traço característico de povoações nascentes e de zonas fronteiriças, onde se dá em escala maior a penetração do conquistador ${ }^{22}$. Em outras ainda, nasce uma tosca apicultura criando-se abelhas em cabaças (caso dos Parecis da Rondônia). Este processo pode ter sido originariamente indígena ou revelar influências européias ou mesmo ser próprio do sertanejo e mestiço do Mato Grosso. Não importa... Importa é ser oriundo da interação tensional meio/sociedade/cultura e, qualquer que seja a forma de sua extração é de vital importância como alimento dos sertanistas, como remédio contra feridas, como estratagema para cobrir o corpo de folhas e atravessar o fogo ateado pelos caiapó. Aqui, novamente se revela a tensão dos processos pois o indígena tanto pode ser o aliado, integrando as expedições como índio meleiro, armado de machados e

22 Novamente aparece a realidade na sua forma composita, significando ao mesmo tempo uma e outra coisa. Exemplar é o caso da técnica primitiva de minerar dos paulistas que se por um lado levava ao rápido esgotamento dos ribeirões, por outro, o próprio esgotamento obrigava o movimento constante da fuga da fome. No dizer do autor: " sem os de Săo Paulo, nẫo se poderiam a proveitar devidamente aquêles sertôes. Mas, com eles, ou só com eles, poderiam constituir-se ali estabelecimentos fixos e duradouros? Fí́is à ánica experiência que podiam ter èm matéria de mineração, logo que se esgotavam os depositos superficiais, acessiveis às suas técnicas rudimentares, tratavam esses descobridores de desampará-los, e sair à busca de novos ribeiros onde reiniciavam, com os mesmos resultados, o mesmo processo. Por vêzes, esqueciam-se de prover o necessário à subsistência, tal a sofreguidão com que, em grandes números, se lançavam sobre alguma pinta mais rica... . Mas a improvidência podia também levá-los a outros descobrimentos. Assim se deu principalmente nos primeiros tempos, quando, tangidos pela fome, abandonaram antigos arraiais em busca de terras menos estéreis, e nessa demanda fizeram achados novos: origem, por sua vez, de novas povoaçðes". IN: Metais e Pedras Preciosas, p.272. 
BLAJ, Ilana e MALUF, Marina. Caminhos e fronteiras: o movimento na obra de Sérgio Buarque de Holanda.

cabaças, facilitando o caminho, quanto pode ser o inimigo hostil, ateando fogo para isolar e matar o sertanista, dificultando pois a fronteira.

O permanente embate envolvendo o processo de interação meio/sociedade/cultura, articula constantemente caminhos e fronteiras, e conduz tanto à "vocação para o espaço" quanto à fixação do colono tal como aparece em todos os níveis na obra de Sérgio Buarque de Holanda. Nada é definitivo, nada é linear. Assim, os "párias" paulistas, os carijó e mamelucos, se muitas vezes são hostís e indesejados, outras o são extremamente úteis.

"O certo é que a situação tende aqui a assumir feições ainda mais críticas, comportando enorme massa de elementos meio aluviais, prole dos carijos e mamelucos, que formam o grosso da população e vivem um pouco à maneira de hospedes numa sociedade que não chegou a dominá-los por completo. Hóspedes geralmente importunos, mas muitas vezes desejados, visto que se mostram capazes de aturar os serviços mais duros e penosos, serviços poupados até a escravos, riqueza que, desbaratada, não mais se restaura. Em outras palavras, ainda que feita de gente inconstante, infiel, ociosa, frequentemente indômita, como se dizia, pode ter sua função social definida e que não se pode facilmente suprir" ${ }^{23}$.

A tensão sempre constante nos processos de sedimentação conduz a hierarquizações igualmente provisórias, onde "a escala social refaz-se naturalmente, à medida em que parece estabilizar-se o povoamento em núcleos fixos" ${ }^{24}$.

Em Metais e Pedras Preciosas o autor retrata a ascensão social de magistrados na ausência de uma verdadeira fidalguia:

"Dos cabos de milicia, quem o diz é ainda o C'ritilo das Cartas Chilenas, alguns não admitem sequer que inflamam suas bengalas, nas mãos lixosas, quando pesam a libra de toucinho ou

23 HOLANDA, Sérgio Buarque de. Movimentos da Populaçäo em São Paulo no séc. XVII, p. 79.

24 HOLANDA, Sergio Buarque de. Metais e Pedras Preciosas, p.296. 
medem o frasco de cachaça, se thes faltam os negros incumbidos de governar suas vendas. O pior é que dessa escória se vai levantando uma raça nova de magistrados, que pareç trazer o sêlo da origem vil, no mais escandaloso desafio às leis do Reino" ${ }^{25}$.

Para melhor nuançar as distinções sociais movediças delineia o surgimento entre os mineiros de uma "aristocracia do espírito":

"Os lugares distintos são disputados cada vez mais, no entanto, pela nova casta de homens, formada geralmente de letrados e doutores. É a única, endinheirada ou não, que se pode opor, fundada em títulos irrecusáveis, aos que baseiam toda a sua força nos grandes cabedais acidentalmente ganhos em lavras e tratos. E é a que procura, muitas vezes, suprir com seus pergaminhos ilustres a carência de fidalgos $e$ filhos de fidalgos" ${ }^{26}$.

Podemos dizer que, era indiferenciado, massa disforme dos tempos iniciais e acabou se estratificando de acordo com padróes trazidos da Europa distante. Fundem-se dois tempos: o criado e o por criar-se, a regra e a brecha, o ideal e o real. Neste jogo de tensões a "terra de adoção" impóe sua concretude.

O legado metropolitano, enquanto patrimônio guardado e necessário sempre se revela pois:

"É preciso ter em conta que até nas sociedades movediças como eram aquelas, podia conservar-se sempre intacto, mesmo em condiçôes desfavoráveis, o prestígio natural de uma existência plácida e estável ${ }^{27}$.

Em Caminhos e Fronteiras o papel deste legado nos aparece também na importância dada às formas de convivência nos povoados, às festas religiosas,

25 HOLANDA, Sérgio Buarque de. Ibidem, p.298.

26 HOLANDA, Sérgio Buarque de. Metais e Pedras Preciosas, p.301.

27 HOLANDA, Sérgio Buarque de. Movimentos da População em São Paulo no séc. XVI, p. 99. 
BLAJ, Ilana e MALUF, Marina. Caminhos e fronteiras: o movimento na obra de Sérgio Buarque de Holanda.

às cerimônias fúnebres, às celebrações régias, eventos que fazem da cera um material valorizado. É a cera da terra, feita pelos índios, que será utilizada, pois a de Portugal seria extremamente dispendiosa para a pobreza paulista. Esta substituição não se revela traumática pois o que importa é a função, a garantia do aparato, $o$ acentuar dos aspectos exteriores da liturgia, que tanto impressionam a quem assiste. No dizer do autor:

"É característico dessa pronunciada disposição de animo dos nossos antepassados, que os fazia preferir quase sempre o aparato à subsistência... Além de realçar certas formas exteriores da liturgia católica, aquelas exatamente que mais impressionam as sensibilidades primitivas e que, por isso mesmo, convinha cultivar nestas paragens, ela concorda bem com o louvor, tradicional na Igreja de Roma, ao produto da "casta e virginal abelha" 28 .

Todas estas celebrações, espetáculos barrocos, acentuam e reforçam este legado metropolitano, talvez como necessidade de se distinguir da identificação pura e simples com o indígena. A assimilação tensional, se conduz a outros patamares de civilização nos caminhos, revelando a apropriação frutífera de elementos da cultura indígena, agora na fronteira, deve ser negada/marcada pela diferenciação.

Esta diferenciação que tenta afirmar a dominação do eu sobre o outro revela-se em diferentes momentos da vida cotidiana. É o uso do sapato pelo sertanista assim que chega à vila, é a distribuição de tochas e velas para as pessoas de maior projeção social nas festas religiosas, é o vender bens pela família do morto para poder arcar com as despesas do funeral, onde se incluíam círios e velas no acompanhamento do enter̆ro ${ }^{29}$; é a importância que assumem as "virtudes mais bonançosas ou inutilitárias" que se manifestam na cultura, na estética, no cuidado com as maneiras ${ }^{30}$; é a observância do beija-mão praticamente durante todo o Império ${ }^{31}$. Enfim, a interação

28 HOLANDA, Sérgio Buarque de. Caminhos e Fronteiras, 'p. 60.

29 HOLANDA, Sergio Buarque de. Caminhos e Fronteiras, p. 60 e 61.

30 HOLANDA, Sérgio Buarque de. Metais e Pedras Preciosas, Op. Cit., p. 300.

31 HOLANDA, Sérgio Buarque de. A Herança Colonial-sua desagregação, p. 38. 
meio/sociedade/cultura revela sua extrema complexidade neste processo constante de afirmação/negação/assimilação. É como se a fronteira, para atingir um novo caminho, precisasse dominar e portanto negar o velho sem no entanto abandoná-lo jamais.

Essa questão da assimilação/produção, do tradicional e de novo, da admissão/rejeição na emergência do mais novo é colocada pelo autor no início do capítulo quarto de Caminhos e Fronteiras:

"Para a análise histórica das influências que podem transformar os modos de vida de uma sociedade é preciso nunca perder de vista a presença no interior do corpo social, de fatores que ajudam a admitir ou a rejeitar a intrusão de hábitos, condutas, técnicas $e$ instituições estranhas à sua herança de cultura. Longe de representarem aglomerados inânimes e aluviais, sem defesa contra sugestões ou imposições externas, as sociedades... dispõem normalmente de forças seletivas que agem em benefício de sua unidade organica, preservando-as tanto quanto possível de tudo que possa transformar essa unidade. Ou modificando as novas aquisiçöes até ao ponto em que se integrem na estrutura tradicional ${ }^{4^{32}}$.

Este mesmo movimento de admissão/negação/assimilação é visto em sua dinâmica no capítulo quarto - "Iguarias de Bugre", - onde o autor analisa a dieta alimentar herdada do indígena pela própria necessidade de subsistência do sertanista em um meio que lhe era hostil. Os alimentos do indígena, em sua forma andeja, por mais primitivos e repugnantes que fossem, transformam-se em iguarias. São as cobras, ratos, raízes, içás torradas, larvas, macacos, etc. que combatem a fome nos caminhos e enraizam-se nas popuỉações mais pobres mesmo nas aldeias. Já as camadas mais favorecidas rejeitam estes hábitos alimentares nas vilas, nesta constante tentativa de afirmar sua dominação pela negação. Ou quase, pois como ironiza Sérgio Buarque de Holanda:

HOLANDA, Sérgio Buarque de. Caminhos e Fronteiras, p. 62. 
BLAJ, Ilana e MALUF, Marina. Caminhos e fronteiras: o movimento na obra de Sérgio Buarque de Holanda.

"Mas entre famílias que se tinham em conta de prestantes e honradas, o uso deprimente já teria sido abolido...quando não o conservassem quase com recato e às suas ocultas ${ }^{\mathbf{1 3} 3}$.

Se nas vilas e aldeias, nas paragens povoadas, $o$ adventício se serve, para sua fixação, de sua cultura material, ampliando assim a base econômica da sociedade, outro é o panorama do sertáo. $\mathrm{O}$ ambiente do sertão torna esta cultura material insatisfatória, obrigando o conquistador a dar continuidade ao processo de rebaixamento de seu padrão de civilidade, processo este que conduz simultaneamente a laços necessários de "solidariedade cultural" com o indígena.

"Entre nossos indígenas e sertanejos os laços que unem o homem ao mundo ambiente são bem mais estreitos que tudo quanto pode alcançar nossa imaginaçäo. A própria arte com que sabem copiar os movimentos, os gestos, as vozes dos animais da selva não significa neles, uma simples mímica; é antes o fruto de uma comunhão assídua com a vida intima da natureza" ${ }^{34}$.

É dessa relação astuciosa entre índio e natureza que Sérgio Buarque de Holanda elabora o quinto capítulo de Caminhos e Fronteiras, "Caça e Pesca".

Dessa íntima comunhão entre homem e natureza brota uma "atenção devinatória", incompreensível para o civilizado. O autor cita um relato de Thomas Whiffen que reproduziremos aqui, já que a nosso ver, nos parece conter a essência dessa comunhão, onde a astúcia é a arma da sobrevivência.

"Thomas Whiffen refere que, percorrendo certa floresta, um indio the declarou, apos rápido exame das arvores e do solo, que quando o sol se achara em determinada posição - isto é, aproximadamente meia hora antes - tinham passado sete homens carregando uma anta, morta em sítio apartado. Em seguida apanhou uma fôlha, onde se podia ver uma pequena mancha de sangue

33 HOLANDA, Sérgio Buarque de. Ibidem, p. 64.

34 HOLANDA, Sérgio Buarque de. Ibidem, p. 77. 
coagulado. O peso demonstrado pela aparência das pegadas dos sete homens indicava que o animal seria uma anta.

Que eram sete, provavam-no iniludivelmente os mesmos rastros. $O$ modo de impressão dos dedos dos pés na terra permitia, além disso, verificar que estariam cansados da longa marcha. Um simples ramo partido, a exsudação da seiva-prossegue a testemunha - basta para advertir ao índio que alguém passou em tal momento por tal lugar. Para mostrar que em um ponto da floresta passara um homem dez minutos antes, o guia indigena exibiu-lhe certa vez uma fôlha colhida do chão. Justamente dez minutos antes tinha começado a chover e a fôlha, revirada pelos pés de algum caminhante, se achava molhada nas duas faces.

Entre esses moradores 'da floresta é uma questão de vida ou morte o saberem a qualquer momento tirar deduções precisas do aspecto do céu, do lado ensombrado das árvores, do vôo das aves, do passo dos animais e, sobretudo, dispor de uma acuidade de sentidos, que ultrapassa qualquer raciocínio" ${ }^{\prime 35}$.

Se Sérgio Buarque de Holanda recorre a tal relato para enfatizar a relação astuciosa entre índios e natureza, sagacidade que transfere para $o$ andejo, ao memo tempo podemos dizer que o usa também de forma quase que metafórica, para revelar ao leitor o modo como o historiador deve trabalhar, isto é que recursos deve utilizar; são sinais e pistas como "o lado ensombrado das árvores", "o vôo das aves", "o passo dos animais". É como se "o lado ensombrado das árvores" advertisse o historiador para os obscuros da história, para as zonas opacas; como se "o vôo das aves" representasse os projetos e promessas futuras de cada acontecimento e, como se "o passo dos animais" fosse uma indicação do próprio trabalho sistemático do pesquisador.

Sinais, pistas e indícios do cotidiano, onde o elemento surpresa, a imprevisibilidade, os avanços e recuos, o silêncio, a ousadia, o mágico são resgatados pelo autor agora para dar conta da oposição entre astúcia e poder, do tenso processo de assimilação onde a "manha" do indígena é transferida e

HOLANDA, Sérgio Buarque de. Caminhos e Fronteiras, p. 34. 
BLAJ, Ilana e MALUF, Marina. Caminhos e fronteiras: o movimento na obra de Sérgio Buarque de Holanda.

introjetada no sertanejo, qualidade vital para o caminho, para a própria expansão/fixação.

Assim, se a arma de fogo é deixada no caminho mas permanece nas fronteiras enquanto sinal de prestígio, de poder, o próprio signo da conquista, por outro lado é a flecha que a substitui, pois guarda a possibilidade, o projeto mesmo da expansáo, da recorrência da vida caminhante. Aqui o mais novo só emergirá em meados do século XIX, quando a fixaçắo, já mais estável, representa o domínio crescente do homem sobre a natureza ${ }^{36}$. Dessa forma, e s6 entāo, a astúcia será substituída pelo poder; o que antes fora a luta pela sobrevivência é agora um meio de demonstrar a superioridade do colono.

"Superioridade que se afirmava na tranquila consciência do poder, raramente na astúcia ${ }^{37}$.

Se no primeiro capítulo de Caminhos e Fronteiras o autor explicita o movimento, nos capitulos seguintes nos convida a percorrer as múltiplas possibilidades do caminho e a vivenciar as tensōes da fronteira. No capítulo sexto, "Botica da Natureza", Sérgio Buarque de Holanda introduz mais um nível da experiência humana, o do imaginário ligado à cura. Já o título, numa primeira apreensăo, encerra a oposiçăo entre o conhecimento proveniente da experimentaçáo (botica) $\mathrm{e}$ as infinitas possibilidades das coisas da "physis" (natureza); na segunda intelecção há um amálgama entre o conhecimento indígena da fauna e da flora, que não são vistos como coisas separadas do homem, e a alquimia - gosto pelo maravilhoso, traço do conquistador, legado europeu,

É importante observar que a fixaçăo do século XIX guarda um caráter movediço, pois como o autor ressalta: a importância cada vez maior da produçăo do açúcar e caf́́ na capitania, logo depois Província, de Săo Paulo, náo se impusera ainda sem contraste. As classes abastadas recrutam-se de preferência, por ora, no meio dos tropeiros mais do que entre lavradores e senhores de engenho", Säo Paulo, p. 432.

HOLANDA, Sérgio Buarque de. Caminhos e Fronteiras, p. 79; o próprio poder 6 também movimento. É o movimento de centralizaçăo/descentralizaç̧ı̆o que o autor aborda no perfodo imperial - o entrechoque constante de forças centripetas e centrifugas. Veja-se A Heranģa Colonial - sua desagregaçảo, Op. cit. especialmente à p. 18, 19 e 20. 
trazendo consigo a consciência cindida que opóe homem e natureza. $O$ resultado final será uma farmacopéia popular, onde cura e promessa são uma só e mesma coisa.

"Há indícios de que mais de um dêsses medicamentos já seriam utilizados pelo gentio antes de qualquer contato com os adventícios. Mas são dignos de interêsse, por outro lado, os processos de racionalização e assimilação a que o europeu sujeitou muitos de tais elementos, dando-lhes novos significados e novo encadeamento lógico, mais em harmonia com seus sentimentos e seus padrões de conduta tradicionais ${ }^{\prime \prime 38}$.

Essa botica ou esta farmacopéia rústica resulta do procedimento analógico empreendido pelo português, que na verdade significa procurar entre os elementos da nova terra propriedades já conhecidas na Europa. A pedra do porco-espinho, bezoar já conhecido pelo europeu, recomendada para vômitos, males de estômago, "aflições do coração", "paixões dos rins", é substituŕda pela pedra do porco do mato.

"Pedras bezoares de grande eficácia existiam também nos veados e antas. Nos sertões da capitania de São Paulo havia "hus Sapos grandes de cornos que chamão Nambicoaras, e os cornos ou orelhas são o melhor unicórnio para se metter na agua, que purifica, apesar da peçonha". Extraurdinário era o efeito de duas pedras encontradas na cabeça do jac aré quando aplicadas aos febricitantes. Era o bastante colocaram-se tais pedras nas mãos do enfêrmo para que logo se extinguisse a feb"e.

Para a mentalidac'e de muitos dos nossos roceiros de hoje têm aplicação terapêtica su servem de amuletos, praticamente, todas partes do corpo dos animais selvagens, que não possam servir 
BLAJ, Ilana e MALUF, Marina. Caminhos e fronteiras: o movimento na obra de Sérgio Buarque de Holanda.

para a alimentação ou manufatura de couros: os chifres, os dentes, as unhas, os ossos, os cascos, as couraças, as gorduras..." ${ }^{39}$.

Sobre esta natureza tão cheia de surpresas e novidades, quando não há analogia possível, o jeito é despejar o gosto pelo maravilhoso, pelo fabuloso, tanto à maneira indígena quanto à maneira européia. Assim, as unhas do tamanduá-bandeira, unidas aos pares, utilizadas pelos naturais da terra como ornamentos, foram incorporadas pelos colonos a fim de afastarem o ar corrompido, já que o tamanduá caminha com as mãos torcidas voltadas contra o ar.

A anhuma, ave que causava espanto, por ser dotada de unicórnio frontal, esporões nas asas, pés enormes, cujo grito lembrava um burro zurrando, guarda em todas as suas partes qualidades mágicas. Faziam-se delas desde mezinhas contra envenenamentos e mordeduras de animais até contra estupor e mau olhado; curava desde picadas de cobras venenosas e até fazia mudo falar.

As condições do ambiente colonial também proporcionaram elementos para a expansão e aplicação de uma medicina escatológica. Sérgio Buarque de Holanda, recuperando Mario de Andrade, observa que:

"À própria utilização do estrume animal para vivificar a terra se relacionaria, de algum modo, ao poder reconfortante $e$ revitalizante que os dejetos assumem com grande frequência para a medicina do povo" ${ }^{\prime 40}$.

Assim, aqui, a urina quente será usada contra inflamações e tumores; misturada com o fumo era purificadora, curando todo o tipo de ferimentos de qualquer gravidade.

39 HOLANDA, Sérgio Buarque de. Caminhos e Fronteiras, p. 91/92. Em Metais e Pedras Preciosas, à p. 289, o autor faz referência a um cirurgiño húngaro, também hervanário, químico e farmacêtico que vivia na regiáo das minas por volta de 1720 e que era experiente "das enfermidades ali reinantes e das mezinhas da terra". 
A magia também estava presente através dos patuás e de orações cujas finalidades eram múltiplas: desde repelir mau olhado até garantir longa vida e cem anos de perdão.

Neste vários níveis onde o maravilhoso está presente, Sérgio Buarque de Holanda enfatiza mais uma vez o processo tensional entre meio/cultural/sociedade, que culmina na própria botica da natureza. Quando isto não é possível, sempre há a possibilidade do milagre e da oração como esta:

"Em nome de Ds. Padre. Em nome de Ds. fo. Em nome do Espirito Santo. Ar vivo, Ar morto, ar de estupor, ar de perlesia, ar renegado, ar escomungado, eu te renego. Em nome da Santicima trindade q. sayas do corpo desta C'reatura, homem ou animal e q. vas para no mar sagrado pa. q. viva sam e alliviado" ${ }^{41}$.

Todo este gosto pelo maravilhoso sofre igualmente transformaçóes à medida que os caminhos vão levando para novas fronteiras, que a expansão vai dando lugar à fixação, que o andar a pé no sertão vai dando lugar às rotas fluviais, ao comércio monçoneiro em Cuiabá. O fabuloso, a magia, o lendário, gradativamente vão sendo substituídos por um realismo mais rude. Nas palavras do autor:

"A verdade é que as monções nunca chegaram a deixar, nos hábitos e na vida social do paulista, nenhuma dessas marcas de vivo colorido, que nascem de uma intimidade grata e quase lírica entre o homem e sua ocupação mais constante. Faltou-lhes a vida fluida, rica de formas, que brota do esforço livremente consentido $e$ que floresce nas lendas, nos usos e nas tradições do povo. A psicologia de nossa gente rude não a acomodava aos rios, como não a acomodou verdadeiramente ao solo" ${ }^{42}$.

"O duro e tosco realismo, que o comércio do Cuyabá refletia, em seus vários pormenores, de que se denuncia no proprio

41 HOLANDA, Sérgio Buarque de. Caminhos e Fronteiras, p. 101.

42 HOLANDA, Sérgio Buarque de. Monçöes, p. 73. 
BLAJ, Ilana e MALUF, Marina. Caminhos e fronteiras: o movimento na obra de Sérgio Buarque de Holanda.

aspecto exterior das embarcações, não é senão o fruto de uma aplicação voluntária de todas as energias ao afã de enriquecimento, de domínio e de grandezas. Se requer audácia, pode-se quase dizer que é uma audácia contrafeita, incapaz, por isso mesmo, de se elevar sobre o plano da realidade mais rasteira e agreste. $O$ que não significa, é certo, exclusão obrigatória das forças sobrenaturais, pois os santos das igrejas, as rezas, os bentinhos, as feitiçarias, pertenceram sempre ao arsenal dos que se embrenhavam no sertão. Mas o céu é aqui simples dependência da terra, disposto sempre a amparar os homens na perseguição de seus apetites mais terrenos" ${ }^{43}$.

Se nos capítulos anteriores o autor esclareceu as forças antagônicas, em permanente tensão, que constituíram a urdidura do cotidiano apreendidas dialeticamente, no sétimo, capítulo de Caminhos e Fronteiras, "Frechas, feras, febres", chegamos junto com Sérgio Buarque de Holanda a uma fronteira, à emergência do mais novo, a um novo dever ser. É a ética desenvolvida no sertão e pelo sertão que está além da adaptação puramente fisiológica do adventício ${ }^{44}$; a contínua vivência no sertão enseja valores e moral próprios e cria na verdade uma raça mais adaptada ao ambiente hostil e portanto mais próxima do bugre. É o contraste entre "razão e costume" e a evidência do último força a revisão do primeiro.

"Nenhum preparo, nenhum excesso de rigor, nenhuma disciplina especial, além da que se forma no hábito hereditário e persistente de enfrentar um meio rústico, poderia fazê-los mais aptos a semelhantes pelejas ${ }^{45}$.

43 HOLANDA, Sérgio Buarque de. Monçōes, p. 75.

44 No movimento de expansăo/fixação, a necessidade de buscar uma nova regra, uma nova ética e portanto uma nova disciplina se impõe. Nos povoados de Minas, o autor recorre ao relato de Antonil para apontar os problemas da sedimentação - tanto a nfvel temporal onde nada havia que "parecesse vocação ou governo algum bem ordenado", quanto ao espiritual onde "curas...ficavam bastante embaraçados, além de embaraçarem a outros, que nunca acabavam de saber a que pastor pertenciam aquêles rebanhos novos", In: Metais e Pedras Preciosas, Op. cit. p. 267.

HOLANDA, Sérgio Buarque de. Caminhos e Fronteiras, p. 146. 
Nesta citação também podemos fazer uma leitura mais metafórica, onde o conhecimento histórico e os procedimentos metodológicos estáo colocados. "Nenhum preparo, nenhum excesso de rigor...nenhum plano prévio" é o próprio fazer e refazer cotidiano, que é imprevisível, singular, multifacetado. Cabe ao historiador resgatar o passado o mais próximo possível desta multiplicidade de possibilidades e promessas, afastando-se portanto da rigidez dos modelos pré-estabelecidos. Este é o próprio ofício do historiador.

Na construção desta nova moral, desta nova ética, o papel da mulher também vai sendo definido e revelado pela pesquisa. Não é uma história da mulher o que faz o autor. Porém faz com que as atividades executadas por ela despontem na história pois a expansão/fixação exigiu a complementariedade entre a alternância das atividades próprias aos elementos masculino e o feminino. Ao lado da curandeira idosa, da tecelã, da debulhedeira de trigo, da que faz o pão, da tecedeira de rede, da quitandeira e junto com elas, somos constantemente confrontados com mulher-Eva, com a serpente.

"O fato de a mulher, de um modo geral, e muito particularmente nos seus periodos críticos, passar por mais vulnerável do que o homem à ação de certas entidades demoniacas, explica as cautelas especiais de que ela costuma ser objeto durante tais periodos" ${ }^{46}$.

Tais períodos seriam os períodos menstruais, de parto e de amamentação onde convergem crendices indígenas, africanas e europeias no sentido de que a mulher estaria influenciada por entidades demoníacas nestas fases e por isso ela É objeto de inúmeros cuidados, como por exemplo pintura corporal como expediente profilático, proibição de banho e entrada nas florestas durante estes períodos "para não se exporem à sanha amorosa das cobras" ${ }^{47}$. Assim lhes é vedado o acesso a certos atos religiosos (exceção feita às mulheres idosas), ao exercício da medicina ritualística e a presenciar o preparo do curare.

46 HOLANDA, Sérgio Buarque de. Caminhos e Fronteiras, p. 127.

47 HOLANDA, Sérgio Buarque de. Ibidem, p. 128. 
BLAJ, llana e MALUF, Marina. Caminhos e fronteiras: o movimento na obra de Sérgio Buarque de Holanda.

Neste momento da obra Caminhos e Fronteiras, após toda uma trajetória onde as partes foram progressivamente colocadas, as múltiplas tensões que daí decorrem explicitadas, a necessidade de uma solidariedade cultural entre índios e adventícios enfatizada, levando primeiro a um rebaixamento no patamar de civilidade e, processo simultâneo, a uma assimilação/produção constante, Sérgio Buarque de Holanda explicita a emergência necessária do mais novo: o mamaluco.

Este não aparece como algo já dado mas constituindo-se historicamente no movimento cotidiano da expansão/fixação. Uma nova vocação, uma nova ética, uma nova moral vão se forjando neste caminho sinuoso:

É certo que, para semelhante mentalidade, o crime traiçoeiro e praticado de emboscada não se acha prêso a idéia de baixeza e indignidade. Não parece necessariamente mais respeitável o triunfo sobre um inimigo implacável, ou apenas incômodo, pelo fato de ser obtido através de luta física. Como a riqueza não parece mais nobilitante se alcançada graças ao trabalho lento e penoso, pois um feliz acaso pode oferecê-la até nas areias do riacho sertanejo.

$\mathrm{Na}$ verdade essa atitude envolve maior desprêzo pelo inimigo do que aquela que leva a feri-lo de frente, com o risco da própria existência. Haveria, neste último caso, uma autêntica valorização do inimigo, que adquire determinados direitos, a começar pelo mais elementar de todos, o de viver e defender a própria vida ${ }^{48}$.

$\mathrm{Na}$ avaliação do autor este mais novo, o mamaluco, seria o indivíduo arredio, desconfiado, cauteloso, amante da solidão, enfim, uma raça soturna, fruto da interação meio/sociedade/cultura já distante do heroísmo do bandeirante.

Os caminhos e as fronteiras no entanto não cessam, o movimento é constante e a "vocação para o espaço", necessidade e atitude ao mesmo tempo, se por um lado garante a fixação da paulista no planalto mediante a agricultura 
e a multiplicação dos povoados ${ }^{49}$, por outro, empurra a expansão tanto para $o$ sul, transformando o sertanista em tropeiro, quanto para noroeste, ao encontro da realização do sonho do ouro e ainda para oeste na constituição do comerciante monçoneiro.

Qualquer destes caminhos constrói uma nova mentalidade, uma nova ética, um novo dever ser.

"O tropeiro é o sucessor direto do sertanista e o precursor, em muitos pontos, do grande fazendeiro: A transição faz-se assim sem violência. $O$ espírito de aventura, que admite e quase exige a agressividade ou mesmo a fraude encaminha-se, aos poucos, para uma ação mais disciplinadora. À fascinação dos riscos e da ousadia turbulenta substitui-se o amor às iniciativas corajosas, mas que nem sempre dão imediato proveito. $O$ amor da pecúnia sucede ao gôsto da rapina. Aqui,...uma ambição menos impaciente que a do bandeirante ensina a medir, a calcular oportunidades, a contar com danos $e$ perdas ${ }^{\prime 50}$.

Na busca do Eldorado:

"Mesmo nas Minas, passada a fase mais cática da exploração aurifera, já se faria sentir a tendência para um tipo de

49 Na primeira parte do texto São Paulo, a necessidade do caminho e a atitude da "vocaçăo para o espaço" são elementos indissocínveis para a compreensão da vida paulista. 0 caminho, em seu sentido mais físico, pode se transformar em obstáculo à própria vocaçăo para o espaço, pois o desenvolvimento da região depende da expansão dos caminhos. $\mathrm{Na}$ década de setenta do século XVIII, "o estado de abatimento a que se viam entáo condenadas as terras do interior, exceção feita de Sorocaba... seria invencivel enquanto . perdurasse a insuficiência e o mau estado crônico dos caminhos que se dirigiam ao litoral. Os quais, prestando-se m à condução de mercadorias, eram por isso mesmo um obstáculo dec'sivo ao incremento da produção agrícola para além dos limites que traçava o pequeno mercado local" (Op. cit, p.418). Com a melhoria nos caminhos, ocorrida em fins do XVIII, a agricultura paulista desenvolve-se e o comércio anima-se garantindo a predominância da área c/p. 421. 
BLAJ, Ilana e MALUF, Marina. Caminhos e fronteiras: o movimento na obra de Sérgio Buarque de Holanda.

estratificação social favorável ao maior prestígio dos que podem aparentar uma digna ociosidade. Não só é esta tendência a mais consentânea com velhas tradições lusitanas e hispânicas, como é a única verdadeiramente mais compativel com os processos de colonização daquelas partes...O próprio lugar das aristocracias de sangue vem a ser vivamente reqüestado, à falta delas, por aquêles que se mostrem aptos à disposição de seus lazeres segundo outra ordem de valôres, ordem essa em que os interêsses simplesmente materiais já não ocupam o primeiro pôsto" ${ }^{51}$.

No caso do comerciante monçoneiro:

"Todavia os elementos de que agora dispóe o sertanista para alcançar sua terra de promissão, vão deixar menos margem ao capricho e à iniciativa individuais. É inevitável pensar que o rio, que as longas jornadas fluviais, tiveram uma ação disciplinadora e de algum modo amortecedora sobre o animo tradicionalmente aventuroso daqueles homens. A própria exiguidade das canoas das monções é um modo de organizar o tumulto, de estimular, senão a harmonia, ao menos a momentânea conformidade das aspirações em contraste. A ausência dos espaços ilimitados, que convidam ao movimento, o espetáculo incessante das densas florestas ciliares, que interceptam à vista o horizonte, a abdicação necessária das vontades particulares, onde a vida de todos está nas mãos, de poucos ou de um só, tudo isso terá de influir poderosamente na mentalidade dos aventureiros, que demandam o sertão remoto. Se o quadro dessa gente aglomerada à popa de um barco tem, em sua aparência, qualquer 
coisa de desordenado, não será a desordem das paixões em alvoroço, mas antes a de ambições submissas e resignadas." ${ }^{52}$.

Concluindo, podemos dizer que Sérgio Buarque de Holanda no livro Caminhos e Fronteiras, na sua primeira parte, como que convida o leitor a seguí-1o no percurso da constituição da vida em São Paulo. Tal percurso acompanha de muito perto os ritmos, temporalidades, tensões do vir a ser da realidade particular do planalto de Piratininga. Assim, no primeiro capítulo, o autor explicita o campo histórico e o modo como este se torna inteligível: é através do movimento dialético onde meio/sociedade/cultura, índio/português/mamaluco, em constante antagonismo, produzem o novo e o mais novo. A partir do segundo capítulo até aproximadamente o sexto, o autor coloca progressivamente as múltiplas forças em oposição: a cultura indígena pré-existente, o legado metropolitano, o embate estre esses elementos, a "solidariedade cultural" sempre guardando uma tensão latente, a diferenciação entre sertão e povoados. A partir do sétimo capítulo estamos todos preparados para receber o mais novo, que se impóe como uma necessidade, como resultado

52 HOLANDA, Sérgio Buarque de. Monçöes, p. 76. Ainda em Monçöes à p. 117: "Com tudo isso, os mais habilidosos ainda conseguem vencer'e acumular cabedais. Destes, sobretudo a partir de meados do século XVIII, quano já está mais regularizado o tráfego fluvial, alguns säo recém-vindos da metrópole e trazem hábitos de previdência, parcimônia e cálculo ainda mal aclimados naquele sertäo remoto. Efetivamente não são numerosos, entre essa gente, os apelidos de familias tradicionais em São Paulo. É, em tudo, uma raça nova, portadora de novos ideais, novas tradiçöes, nova mentalidade-mentalidade de retalhistas, não de aventureiros ou conquistadores". No entanto esta raça nova, esta sedimentação provisória será continuamente despertada para novos caminhos e fronteiras: "É a partir da data de sua viagem (John Mawe), precisamente da data de sua viagem, que certas virtualidades ainda indecisas väo despertar a antiga capitania pra uma vida nova, fazendo-a abandonar aquela posiçäo fronteiriça que por longo tempo ocupara na América lusitana... "in Säo Paulo, p. 42.9. Durante o Império o dinam ismo continua: "Na época de D. Pedro I, que bem se poderia chamar de descolonização do Brasil, apesar da força efetiva ou presumida de chumbeiros e corcundas, insinuam-se no país transformaçöes imprevistas e, não raro, irreversíveis. Algumas se naturalizam facilmente, outras virão tumultuar sradiçöes renitentes. Só o tempo irá compor esses contrastes, ou melhor, apaziguá-los, na longa paz do segundo reinado", In: A Herança Colonial sua desagregaçäo, op. cit. p. 39. 
BLAJ, Ilana e MALUF, Marina. Caminhos e fronteiras: o movimento na obra de Sérgio Buarque de Holanda.

mesmo do movimento dialético: o mamaluco. É uma sedimentação provisória, de uma nova raça, uma nova vocação. Mas, será o novo provisório, já que novos caminhos e novas fronteiras impõem-se como uma necessidade histórica e assim:

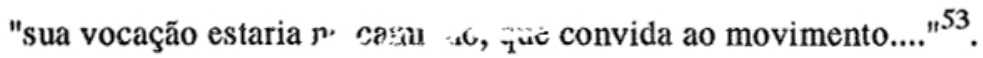

\begin{abstract}
Taking as point of reference the suggestive title of Sergio Buarque de Holanda's book Caminhos e Fronteiras, the authors grasp essential peculiarities of the historian's works as synthesized in the idea of movement. The article analyses the historian's methods of interpretation in relation to his literary style. Focusing on his book on the changes in the daily lives of the first paulista colonizers, mainly through the gradual adoption of the indian's ways of living, they analyse the historian's peculiarities in exploring the interaction between geographical habitat, society and culture.
\end{abstract}

53 HOLANDA, Sérgio Buarque de. Monções, p. 20. 